\title{
Purification and characterization of a collagenase from Penicillium sp. UCP 1286 by polyethylene glycol-phosphate aqueous two-phase system
}

\author{
Maria Carolina de Albuquerque Wanderley ${ }^{a}$, José Manoel Wanderley Duarte Neto ${ }^{\text {a }}$ \\ Wendell Wagner Campos Albuquerque ${ }^{\mathrm{b}}$, Daniela de Araújo Viana Marques ${ }^{\mathrm{c}}$, \\ Carolina de Albuquerque Lima ${ }^{\mathrm{d}}$, Sara Isabel da Cruz Silvério ${ }^{\mathrm{e}}$, José Luiz de Lima Filho ${ }^{\mathrm{a}}$, \\ José António Couto Teixeira ${ }^{\mathrm{e}}$, Ana Lúcia Figueiredo Porto ${ }^{\mathrm{b},}$ " \\ ${ }^{a}$ Laboratory of Immunopathology Keizo Asami (LIKA), Federal University of Pernambuco, Av. Prof. Moraes Lins do Rego, s/n, 50670-901, Recife, PE, Brazil \\ ${ }^{\mathrm{b}}$ Department of Morphology and Animal Physiology, Federal Rural University of Pernambuco, Av. Dom Manoel de Medeiros, s/n, 52171-900, Recife, PE, \\ Brazil \\ ' Serra Talhada Campus, University of Pernambuco (UPE), Av. Afonso Magalhães, s/n, Serra Talhada, PE, Brazil \\ ${ }^{\mathrm{d}}$ Faculty of Science, Education and Technology of Garanhuns, University of Pernambuco-UPE, Av. Capitão Pedro Rodrigues, $n^{\circ}$ 105, Garanhuns, PE, Brazil \\ e Centre of Biological Engineering, University of Minho, Campus Gualtar, 4710-057, Braga, Portugal
}

\section{A R T I C L E I N F O}

\section{Article history:}

Received 11 January 2017

Received in revised form

22 February 2017

Accepted 22 February 2017

Available online 24 February 2017

Keywords:

Collagenolytic enzyme

Collagen

ATPS

Purification

\begin{abstract}
A B S T R A C T
Collagenases are proteolytic enzymes capable of degrading both native and denatured collagen, reported to be applied in industrial, medical and biotechnological sectors. Liquid-liquid extraction using aqueous two-phase system (ATPS) is one of the most promising bioseparation techniques, which can substitute difficult solid-liquid separation processes, offering many advantages over conventional methods including low-processing time, low-cost material and low-energy consumption. The collagenase produced by Penicillium sp. UCP 1286 showed a stronger affinity for the bottom salt-rich phase, where the highest levels of collagenolytic activity were observed at the center point runs, using $15.0 \%(\mathrm{w} / \mathrm{w})$ PEG $3350 \mathrm{~g} / \mathrm{mol}$ and $12.5 \%(\mathrm{w} / \mathrm{w})$ phosphate salt at $\mathrm{pH} 7.0$ and concentration. The enzyme was characterized by thermal stability, $\mathrm{pH}$ tolerance and effect of inhibitors, showing optimal collagenolytic activity at $37^{\circ} \mathrm{C}$ and $\mathrm{pH} 9.0$ and proved to be a serine protease. ATPS showed high efficiency in the collagenase purification, confirmed by a single band in SDS/PAGE, and can in fact be applied as a quick and inexpensive alternative method.
\end{abstract}

(C) 2017 Elsevier Inc. All rights reserved.

\section{Introduction}

Collagen is a protein composed of three peptide chains associated in a triple helical structure, found in connective tissues of animals and corresponding to about $30 \%$ of the entire protein content in the human body [1,2]. Collagenases are proteolytic enzymes capable of degrading both the native and denatured collagen [3-5] and they are related to physiological and pathological processes, with many applications in industry, medicine and biotechnology, as collagen hydrolysis, wound repair and production of bioactive peptides [5-9].

\footnotetext{
* Corresponding author

E-mail address: analuporto@yahoo.com.br (A.L.F. Porto).
}

Among several methods described in the literature for separation and purification of proteases, ultrafiltration, precipitation and chromatography are the most common used [10]. However, for industrial scale, such procedures are not considered profitable due their high cost and long processing time [11]. Thus, the search for alternative protease purification methods has become increasingly common [12]. Liquid-liquid extraction using aqueous two-phase systems (ATPS) is one of the most promising bioseparation techniques which can, although being simple and inexpensive, be used in place of difficult solid-liquid separation processes, in the initial or subsequent purification steps [13].

Aqueous two-phase system has potential industrial applications because its: environment-friendly; low cost, processing time and power consumption; capacity of continuous operation and ease of scaling-up. Composed by a mixture of two polymers or a polymer 
and a salt (constituting two aqueous phases), ATPS has been used in bioprocesses which aim to recover and purify many biological products including proteins, genetic material, bionanoparticles, cells and organelles [12,14-16].

ATPS has been used to partition and recover several molecules as: human antibodies [17], catalase [18], clavulanic acid [19,20], polygalacturonases [21], citrinin [22], pepsin [23], bromelain [24,25], tannase [26], xylanase [27], lipase [28-30], elastase [31], alkaline protease [12], laccase [32], fibrinolytic proteases [33,34] and others. ATPS formed by PEG and phosphate has been described in collagenase extraction due PEG's favorable physical properties, particularly as regards viscosity and differences in density between the phases [7,13].

The present work aims to extract, purify and characterize a collagenase produced by Penicillium sp. UCP 1286, isolated from Caatinga's soil (Pernambuco - Brazil), and determine the best conditions for purification by ATPS. For this purpose, a $2^{4}$ full factorial design was applied to determine the optimal levels of PEG molar mass, pH, phosphate salt and PEG concentrations.

\section{Materials and methods}

\subsection{Microorganism}

Penicillium sp. strain (UCP 1286) isolated from the soil of Serra Talhada, PE, Brazil (Caatinga biome) was obtained from UCP Catholic University of Pernambuco Collection (UNICAP).

\subsection{Culture medium}

Malt Extract Agar was used as maintenance medium composed by: malt extract $(0.5 \%)$, peptone $(0.1 \%)$, glucose $(2 \%)$ and agar $1.5(\%)$. The preparation of culture medium followed the methods of Lima et al. [35], with modifications, composed by: gelatin $(0.5 \% \mathrm{w} / \mathrm{v})$, $\mathrm{MgSO}_{4} \cdot 7 \mathrm{H}_{2} \mathrm{O}(0.025 \mathrm{w} / \mathrm{v}), \mathrm{K}_{2} \mathrm{HPO}_{4}(1.5 \mathrm{w} / \mathrm{v}), \mathrm{FeSO}_{4} \cdot 7 \mathrm{H}_{2} \mathrm{O}(0.015 \mathrm{w} /$ $\mathrm{v}), \mathrm{CaCl}_{2}(0.025 \mathrm{w} / \mathrm{v})$ and mineral solution $(1 \% \mathrm{v} / \mathrm{v})$.

\subsection{Azocoll assay for collagenolytic enzyme activity determination}

Azo dye-impregnated collagen (Azocoll; Sigma Chemical Co., St Louis, MO) assay was carried out according to a modified version of the method developed by Ref. [36]. The absorbance of supernatant was measured at $520 \mathrm{~nm}$ by a UV-Vis spectrophotometer (model B582; Micronal, São Paulo, Brazil). One unit of enzyme activity (U) was defined as the amount of enzyme, per milliliter, necessary to increase the absorbance by 0.1 , because of the formation of azo dyelinked soluble peptides.

\subsection{Protein measurement}

Protein concentration was determined by the method of Bradford [37] modified by the use of "Coomassie Blue Bright G-250" to bind proteins. The calibration curve was obtained from stock solutions of bovine serum albumin (BSA).

\subsection{Aqueous two-phase system preparation}

A phosphate buffer solution (PBS, $40 \% \mathrm{w} / \mathrm{w}$ ) was prepared according to Lima et al. [7], at room temperature (25 $\left.\pm 1^{\circ} \mathrm{C}\right)$. Subsequently, PEG solutions with different molar masses, specifically 1500, 3350 and $8000 \mathrm{~g} / \mathrm{mol}$, were dissolved $(60 \% \mathrm{w} / \mathrm{w})$ in PBS and transferred to $15-\mathrm{mL}$ graduated tubes. Aliquots of the fermented broth corresponding to $20 \%(\mathrm{w} / \mathrm{w})$ of the total mass of system were later added, along with enough water to give a $10 \mathrm{~g}$ system. After $1 \mathrm{~min}$ of vortex shaking, the two phases were separated by settling for 120 min. The volume of each phase was then measured, and the protein concentration and collagenase activity were determined. To avoid interference of PEG and phosphate salt, all the samples were compared with protein-free standard solutions, with the same phase composition.

\subsection{Experimental design}

A $2^{4}$ full factorial design was utilized to evaluate the influence of four independent variables, namely PEG molar mass $\left(x_{1}\right)$, PEG concentration $\left(\mathrm{x}_{2}\right), \mathrm{pH}\left(\mathrm{x}_{3}\right)$, and phosphate salt concentration $\left(\mathrm{x}_{4}\right)$ on the parameters of partition coefficient, activity yield and purification factor of the collagenolytic enzyme. The experimental design included 16 runs and 4 repetitions at the central point, which were necessary to calculate the pure error (Table 1 ). A linear regression model was employed to predict the response, according to eq. (1):

$R=b 0+\sum b i x i+\sum b j x j+\sum b i j x i x$

where b0 is the interception coefficient, bi and bj are the linear coefficients, bij are the interaction coefficients and $\mathrm{xi}$ and $\mathrm{xj}$ are the independent variables. The goodness of fit of the model was evaluated by the coefficient of determination $\left(R^{2}\right)$ and the analysis of variance (ANOVA); the first-order model equation was determined by Fischer's test. The experimental and predicted values were compared and the developed model validated with Statistica 8.0 software (StatSoft Inc., Tulsa, OK, USA).

\subsection{Determination of the partition coefficient, activity yield and purification factor}

The collagenase partition coefficient was determined as the ratio of the collagenase activity in the top phase $\left(A_{T}\right)$ to that in the bottom phase $\left(A_{B}\right)$ :

$K=\frac{A_{T}}{A_{B}}$

The activity yield was defined as the ratio of $A_{B}$ to the initial activity in the fermentation broth $\left(A_{F}\right)$ and expressed as a percentage:

$Y=\left(\frac{A_{B}}{A_{F}}\right) \times 100$

The purification factor was calculated as the ratio of the specific activity in the bottom phase $\left(A_{B} / C_{B}\right)$ to the initial specific activity in the fermentation broth before partition $\left(A_{F} / C_{F}\right)$ :

$P F=\frac{\frac{A_{B}}{C_{B}}}{\frac{A_{F}}{\bar{C}_{F}}}$

where $C_{B}$ and $C_{F}$ are the protein concentrations, expressed in $\mathrm{mg} /$

Table 1

Factor levels of the $2^{4}$-full factorial design used to investigate collagenase partition and purification by ATPS.

\begin{tabular}{llll}
\hline \multirow{2}{*}{ Factor } & Level & & \\
\cline { 2 - 4 } & Low $(-1)$ & Center $(0)$ & High $(+1)$ \\
\hline PEG molar mass $\left(\mathrm{M}_{\mathrm{PEG}}\right)$ & 1500 & 3350 & 8000 \\
PEG concentration $\left(\mathrm{C}_{\mathrm{PEG}}\right)$ & 12.5 & 15.0 & 17.5 \\
Phosphate concentration $\left(\mathrm{C}_{\mathrm{PHOS}}\right)$ & 10.0 & 12.5 & 15.0 \\
$\mathrm{pH}$ & 6.0 & 7.0 & 8.0 \\
\hline
\end{tabular}


$\mathrm{mL}$, in the bottom phase and the fermentation broth, respectively.

\subsection{Characterization of the extracted collagenase}

\subsubsection{Effects of $p H$ and temperature on the collagenolytic enzyme} activity and stability

To evaluate the effects of $\mathrm{pH}$ on the collagenolytic enzyme activity, the pHs of the reaction mixtures containing $0.5 \%(\mathrm{w} / \mathrm{v})$ azocoll were varied over the range of 3.0-11.0. The buffers used were $0.05 \mathrm{M}$ citrate (pH 3.0 to 6.0), $0.05 \mathrm{M}$ Tris- $\mathrm{HCl}$ ( $\mathrm{pH} 7.0$ to 9.0), and $0.05 \mathrm{M}$ carbonate-bicarbonate ( $\mathrm{pH} 10.0$ to 11.0 ). For the stability tests, the filtrate culture was incubated (from 1 to $24 \mathrm{~h}$ ) at $4{ }^{\circ} \mathrm{C}$ (temperature at which the enzyme thermoinactivation is expected to be low) in the above-described buffers at different $\mathrm{pH}$ values.

Buffer solutions (0.05 M Tris- $\mathrm{HCl}, \mathrm{pH}$ 9) containing $0.5 \%(\mathrm{w} / \mathrm{v})$ azocoll were used to investigate the temperature effects on the enzyme activity. To determine the optimal temperature, the reaction mixtures were incubated at temperatures from 25 to $70{ }^{\circ} \mathrm{C}$, whilst for the thermostability tests the enzymes were preincubated for 15-180 $\mathrm{min}$ at the same temperatures. The residual activity was calculated as the ratio between the enzymatic activity observed at the end of each reaction time and the initial activity, expressed as percentage.

\subsubsection{Substrate specificity}

To test the substrate specificity, the proteolytic activities of the extracellular collagenolytic enzyme produced by Penicillium sp. UCP 1286 and a commercial collagenase were determined by using insoluble collagen (type I and type V), gelatin and azocasein as substrates. Azocasein was used to compare the enzyme specificity.

The enzyme activity using insoluble collagen as substrate was performed according to Endo et al. [47]. The standard reaction mixture, containing $25 \mathrm{mg}$ of collagen (type I and $\mathrm{V}$, from bovine Achilles tendon) in $5 \mathrm{~mL}$ of $0.05 \mathrm{M}$ Tris- $\mathrm{HCl}$ buffer ( $\mathrm{pH} 7.0$ ), was incubated with $1 \mathrm{~mL}$ of enzyme samples at $37{ }^{\circ} \mathrm{C}$. The amount of free amino groups released was measured by the ninhydrin method of Ref. [38]. One activity unit (U) was defined as the number of $\mu \mathrm{mol}$ of L-leucine released as a result of the action of $1 \mathrm{~mL}$ culture filtrate containing collagenolytic enzyme, after $18 \mathrm{~h}$ at $37^{\circ} \mathrm{C}$.

Collagenolytic enzyme activity on gelatin was determined by the methods of Ref. [39], slightly modified. The reaction was carried out at $37{ }^{\circ} \mathrm{C}$ for $18 \mathrm{~h}$ after the addition of $0.1 \mathrm{~mL}$ of the enzyme solution to $1.0 \mathrm{~mL}$ of a solution containing $2 \mathrm{mg}$ gelatin in $0.05 \mathrm{M}$ Tris-HCl buffer ( $\mathrm{pH} 7.5)$. The reaction was stopped by the addition of $0.1 \mathrm{~mL}$ of $10 \%(\mathrm{w} / \mathrm{v})$ trichloroacetic acid. The medium was centrifuged at $10,000 \times g$ for $10 \mathrm{~min}$. The supernatant $(0.2 \mathrm{~mL})$ was mixed with $0.5 \mathrm{~mL}$ of ninhydrin solution, heated at $100{ }^{\circ} \mathrm{C}$ for $10 \mathrm{~min}$, cooled in ice water for $5 \mathrm{~min}$, and further diluted with $2.5 \mathrm{~mL}$ of $50 \%$ $(\mathrm{v} / \mathrm{v}) 1$-propanol. After centrifugation at $12,000 \times \mathrm{g}$ for $10 \mathrm{~min}$, the absorbance of the mixture was measured at $570 \mathrm{~nm}$. One unit (U) of enzyme activity was expressed as $\mu \mathrm{mol}$ of L-leucine equivalents released per min.

The enzyme activity on azocasein was determined according to Leighton et al. [48], with $1 \%(\mathrm{w} / \mathrm{v})$ azocasein in a $0.1 \mathrm{M}$ Tris- $\mathrm{HCl}$ buffer ( $\mathrm{pH}$ 7.2). One unit (U) of protease activity was defined as the amount of enzyme required to raise the optical density at $440 \mathrm{~nm}$ by one unit after $1 \mathrm{~h}$.

\subsubsection{Effect of inhibitors}

The effects of protease inhibitors were tested following their manufacturer's guide. The inhibitors tested were: phenylmethylsulfonyl fluoride (PMSF) for serine proteases, ethylenediaminetetraacetic acid (EDTA) for metalloproteases, and iodoacetic acid (IAA) for cysteine proteases, at the concentration of $10 \mathrm{mM}$. For the sensitivity determination, the enzyme solution was pre-incubated for $30 \mathrm{~min}$ at $37^{\circ} \mathrm{C}$ in the presence of the inhibitors. The residual activity was determined as the percentage of the proteolytic activity in the control sample (without any inhibitor). The collagenolytic activity was performed using the azocoll method.

\subsubsection{Polyacrylamide gel electrophoresis (SDS-PAGE)}

Samples were analyzed by SDS-PAGE in a $15 \%$ polyacrylamide gel, according to Ref. [40]. The protein molecular markers were phosphorylase b (97.0 kDa), bovine serum albumin $(66.0 \mathrm{kDa})$, ovalbumin (54.0 kDa), carbonic anhydrase (30.0 kDa), trypsin inhibitor (20.1 kDa) and $\alpha$-lactalbumin (14.4 kDa). The gel was loaded with $20 \mu \mathrm{L}$ of the concentrated enzyme, and subjected to electrophoresis at a constant current of $100 \mathrm{~V}$. Gel was stained with $0.25 \%$ (w/v) Comassie Brilliant Blue R-250 in methanol-acetic acid-water (45:10:45) and unstained in the same solution without dye.

\subsubsection{Zymogram}

The proteolytic activity of the purified band was confirmed by zymogram analysis. To prepare a zymogram, the enzyme was mixed under non-reducing conditions with SDS-PAGE sample buffer and electrophoresed in a $15 \%$ polyacrylamide gel with $0.1 \%$ $(\mathrm{w} / \mathrm{v})$ gelatin incorporated as substrate. The gel was loaded with $20 \mu \mathrm{L}$ of the enzyme sample, subjected to electrophoresis at a constant current of $100 \mathrm{~V}$ at $4{ }^{\circ} \mathrm{C}$ and incubated for $1 \mathrm{~h}$ at room temperature with $2.5 \%(\mathrm{v} / \mathrm{v})$ Triton $\mathrm{X}-100$ and for $18 \mathrm{~h}$ at $37{ }^{\circ} \mathrm{C}$ in $50 \mathrm{mM}$ Tris- $\mathrm{HCl}$ buffer, $\mathrm{pH}$ 9.0. The gel was stained and unstained as described in the previous section.

\section{Results and discussion}

Table 2 shows the results of the $2^{4}$ factorial design for extraction of the collagenase from Penicillium sp. UCP 1286 by ATPS. The observed responses were the collagenolytic activities of top $\left(A_{T}\right)$ and bottom $\left(A_{B}\right)$ phases, the partition coefficient $(K)$, the activity yield $(\mathrm{Y})$ and the purification factor $(\mathrm{PF})$ of bottom phases. It should be taken into account that the run 5 did not form a biphasic system, probably because the concentrations of the components were below or very near the critical point of the binodal curve, point in which the systems are monophasic [41].

Collagenase obtained from ATPS showed high affinity for the bottom phase, where the highest collagenolytic activity values (797-812 U/mL) were observed at the center point runs, using $15.0 \%(\mathrm{w} / \mathrm{w})$ PEG $3350 \mathrm{~g} / \mathrm{mol}$ and $12.5 \%(\mathrm{w} / \mathrm{w})$ phosphate salt at $\mathrm{pH}$ 7.0.

The partition coefficient parameter, which is used to evaluate the separation of biomolecules in ATPS, was not statistically analyzed because all calculated values were lower than 1 in all the runs, with values between 0.01 and 0.02 . That means an almost complete migration of the collagenase enzyme to the salt-rich phase.

These results indicate that large-sized polymers create a repulsive effect on the collagenase partition, which leads then to a decrease in the partition coefficient. For the extracted collagenase, that decrease may be associated with the higher hydrophobicity of the top phase in addition to the volume exclusion effect resulted from high values of the PEG molar mass [20]. Babu et al. [42] suggest there be a relation between the MPEG and the partition coefficient $(\mathrm{K})$, since the increase in the molar mass tends to reduce the available space (excluded volume) for biomolecules in the top phase, which induces their migration to the bottom phase.

Lima et al. [7] performed a $2^{4}$ factorial design for purification of collagenase produced by Penicillium aurantiogriseum and found the best enzyme activity in the top phase, using $17.5 \%$ (w/w) PEG $1500 \mathrm{~g} / \mathrm{mol}$, and $15.0 \%(\mathrm{w} / \mathrm{w})$ phosphate salt at $\mathrm{pH}$ 6.0. That 
Table 2

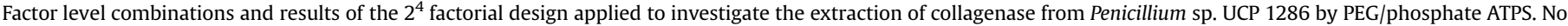
biphasic system was observed in the run 5 .

\begin{tabular}{|c|c|c|c|c|c|c|c|c|c|}
\hline Run & $\mathrm{M}_{\mathrm{PEG}}^{\mathrm{a}(\mathrm{g} / \mathrm{mol})}$ & $\mathrm{C}_{\mathrm{PEG}}{ }^{\mathrm{b}(\% \mathrm{w} / \mathrm{w})}$ & $\mathrm{pH}$ & $\mathrm{C}_{\mathrm{PHOS}}{ }^{\mathrm{C}(\% \cdot \mathrm{w} / \mathrm{w})}$ & $\begin{array}{l}A_{T}^{d} \\
(U / m l)\end{array}$ & $\begin{array}{l}A_{B}{ }^{e} \\
(U / m l)\end{array}$ & $\mathrm{K}^{\mathrm{f}}$ & $\mathrm{Y}^{g}(\%)$ & $\mathrm{PF}^{\mathrm{h}}$ \\
\hline 1 & 1500 & 12.5 & 6 & 10 & 8.15 & 458.00 & 0.02 & 46.81 & 5.65 \\
\hline 2 & 8000 & 12.5 & 6 & 10 & 0.86 & 545.00 & 0.01 & 55.71 & 12.26 \\
\hline 3 & 1500 & 17.5 & 6 & 10 & 5.56 & 377.50 & 0.01 & 38.59 & 4.02 \\
\hline 4 & 8000 & 17.5 & 6 & 10 & 2.65 & 405.00 & 0.01 & 41.40 & 12.23 \\
\hline 5 & 1500 & 12.5 & 8 & 10 & - & - & - & - & - \\
\hline 6 & 8000 & 12.5 & 8 & 10 & 1.37 & 411.00 & 0.01 & 42.01 & 10.03 \\
\hline 7 & 1500 & 17.5 & 8 & 10 & 8.20 & 373.50 & 0.02 & 38.18 & 2.74 \\
\hline 8 & 8000 & 17.5 & 8 & 10 & 0.90 & 332.00 & 0.01 & 33.94 & 7.29 \\
\hline 9 & 1500 & 12.5 & 6 & 15 & 3.24 & 400.00 & 0.01 & 40.89 & 6.63 \\
\hline 10 & 8000 & 12.5 & 6 & 15 & 3.45 & 332.50 & 0.01 & 33.99 & 12.02 \\
\hline 11 & 1500 & 17.5 & 6 & 15 & 7.03 & 504.00 & 0.01 & 51.52 & 7.81 \\
\hline 12 & 8000 & 17.5 & 6 & 15 & 3.62 & 305.50 & 0.01 & 31.23 & 10.78 \\
\hline 13 & 1500 & 12.5 & 8 & 15 & 8.00 & 553.50 & 0.01 & 56.58 & 5.56 \\
\hline 14 & 8000 & 12.5 & 8 & 15 & 2.80 & 348.50 & 0.01 & 35.62 & 9.69 \\
\hline 15 & 1500 & 17.5 & 8 & 15 & 6.50 & 362.00 & 0.02 & 37.00 & 2.98 \\
\hline 16 & 8000 & 17.5 & 8 & 15 & 5.06 & 264.50 & 0.02 & 27.04 & 4.73 \\
\hline $17(C)$ & 3350 & 15 & 7 & 12.5 & 1.15 & 797.00 & 0.01 & 81.47 & 25.23 \\
\hline $18(C)$ & 3350 & 15 & 7 & 12.5 & 1.06 & 797.00 & 0.01 & 81.47 & 24.55 \\
\hline $19(\mathrm{C})$ & 3350 & 15 & 7 & 12.5 & 1.02 & 799.50 & 0.01 & 81.72 & 25.31 \\
\hline $20(C)$ & 3350 & 15 & 7 & 12.5 & 1.11 & 812.00 & 0.01 & 83.00 & 27.61 \\
\hline
\end{tabular}

-, no biphasic system.

Pure error of the experiments $=0.53$.

a PEG molar mass.

b PEG concentration.

c Phosphate concentration.

d Collagenolytic activity of top phase.

e Collagenolytic activity of bottom phase.

f Partition coefficient.

g Activity yield of bottom phase.

Purification factor of bottom phase.

preferential migration for the top phase actually difficults the recovery of final product, since it is composed by PEG. Rosso et al. [13] used ATPS for purification of collagenase produced by $P$. aurantiogriseum and observed similar partition of the target protein between the two phases, probably due a salting out effect proportional to the volume exclusion effect, using 20\% (w/w) PEG molar mass $550 \mathrm{~g} / \mathrm{mol}$ and $17.5 \%(\mathrm{w} / \mathrm{w})$ potassium phosphate.

Table 3 shows the statistical analysis for the activity yield, where all independent variables and their interactions (bold numbers) were statistically significant at a confidence level of 95\%, except for the PEG molar mass $\left(x_{1}\right)$, which was maintained in the model only

Table 3

Estimated effects of the independent variables and their influence on the activity yield $(Y)$ of the collagenase.

\begin{tabular}{lll}
\hline Independent variable and interaction & Estimated effect & $p$ value \\
\hline Mean/intercept & $\mathbf{4 6 . 9 1}$ & $<0.05$ \\
${ }^{*} x_{1}\left(M_{P E G}\right)$ & -1.08 & 0.06 \\
$x_{2}\left(C_{P E G}\right)$ & $-\mathbf{1 . 5 9}$ & $<0.05$ \\
$x_{3}(p H)$ & $-\mathbf{8 . 7 2}$ & $<0.05$ \\
$x_{4}\left(C_{P H O}\right)$ & $\mathbf{2 . 1 5}$ & $<0.05$ \\
$x_{1} x_{2}$ & $\mathbf{6 . 8 4}$ & $<0.05$ \\
$x_{1} x_{3}$ & $\mathbf{2 . 7 9}$ & $<0.05$ \\
$x_{1} x_{4}$ & $\mathbf{- 1 3 . 4 4}$ & $<0.05$ \\
$x_{2} x_{3}$ & $\mathbf{2 . 0 8}$ & $<0.05$ \\
$x_{2} x_{4}$ & $\mathbf{- 3 . 4 8}$ & $<0.05$ \\
$x_{3} x_{4}$ & $\mathbf{8 . 3 7}$ & $<0.05$ \\
\hline
\end{tabular}

PEG molar mass $\left(x_{1}\right)$.

PEG concentration $\left(x_{2}\right)$.

$\mathrm{pH}\left(x_{3}\right)$.

phosphate salt concentration $\left(x_{4}\right)$.

*Independent variable effect not statistically significant at a confidence level of $95 \%$. to minimize the error determination. As shown in Table 2, $80 \%$ of the activity yield values were found in the bottom phase of center point runs. Lima et al. [7] reported lower yields, with the highest value obtained on the run 15 (61.68\%), using 17.5\% (w/w) PEG 8000 $(\mathrm{g} / \mathrm{mol})$ and $15 \%(\mathrm{w} / \mathrm{w})$ phosphate salt $(\mathrm{pH} 8.0)$, although that run did not present the highest purification factor (2.65). Rosso et al. [13] showed high efficiency values for a collagenase from $P$. aurantiogriseum, with the highest yield found in the top phase (376.8\%) of the run 3, which used 20\% (w/w) PEG $550 \mathrm{~g} / \mathrm{mol}$ and $12.5 \%(\mathrm{w} / \mathrm{w})$ phosphate. Following the authors, the highest yield was not related to the highest purification factor, which was found in the run number 7 (equivalent to 23.5) by using 20\% (w/w) PEG 550 and $17.5 \%(\mathrm{w} / \mathrm{w})$ phosphate salt.

The analysis of the $P F$ response showed that only PEGMM and $\mathrm{pH}$ (independent variables) were statistically significant at a confidence level of $95 \%$. Similar to the observed partition coefficient, an increase in the PEGMM affected positively the purification factor of the enzyme, i.e. the volume occupied by the polymer is proportional to its concentration and chain length (or molar mass), resulting in a reduced space for biomolecules in the top phase of the system and consequently their partition to the bottom phase, the so-called volume exclusion effect $[13,24,41,43]$.

It was observed that, at low $\mathrm{pH}$ values, the enzyme migrated preferentially to the bottom salt-rich phase. The $\mathrm{pH}$ of the system influences the ionizable groups of a protein and alters the protein surface charges. At high $\mathrm{pH}$ values, the protein is more negatively charged, and thus the partition coefficient of proteins increases proportionally to the $\mathrm{pH}$ increment [44] due to electrostatic interactions between the proteins and PEG [45].

The concentration of proteins partitioned in the salt-rich phase, considering the runs at the center point, were lower than the one in the PEG-rich phase (0.007 and $0.166 \mathrm{mg} / \mathrm{mL}$, respectively), and this 


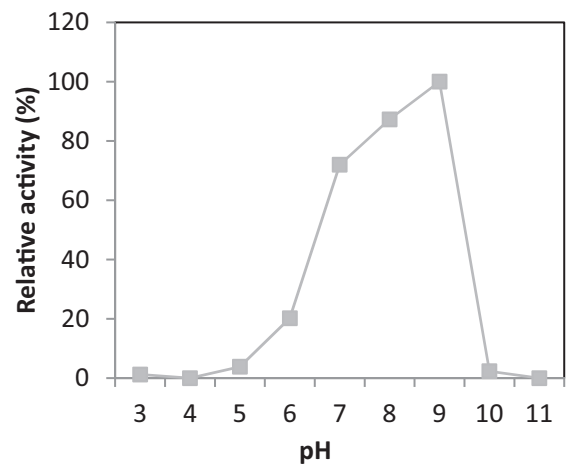

B

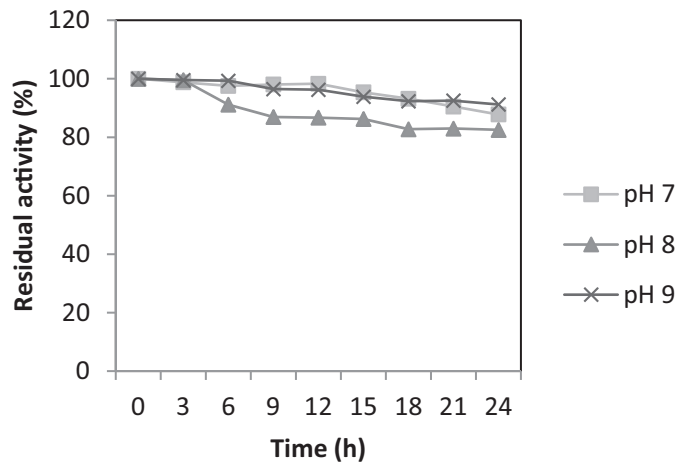

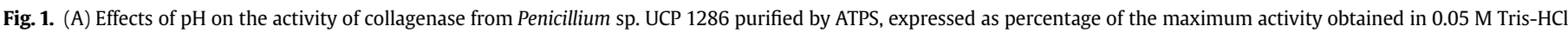

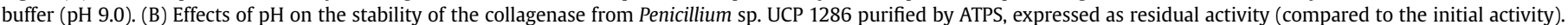
Each value represents the mean of two experiments, and the error bars show the standard deviations.

low protein content in the bottom phase (corresponding to the collagenase enzyme) was reflected in the high purification factor $(P F)$ values, which were found to be well above 1 , as shown in Table 2.

Rodríguez-Durán et al. [26] reported that contaminated molecules were preferentially partitioned in the PEG phase. A possible explanation for this would be the fact that enzymes from different sources have significant variations in their molecular weight. Low molecular weight proteins, which contain hydrophobic residues on their surface, are preferably partitioned in PEG phase due Van der Waals forces. On the other hand, for high weight molecules, the partition is driven by entropic effect and the protein is partitioned into the salt-rich phase. Collagenases are intermediate molecular weight in the range of 60-130 kDa. Probably, the pH and PEGMM effects on the system, protein charges and molecular weight, all together, have influenced the collagenase preferential partition towards the salt-rich phase. Several studies have shown other enzymes with similar properties $[23,46]$.

Fig. 1(A) shows the $\mathrm{pH}$ dependence of the collagenolytic activity. The enzyme was found to be very active between $\mathrm{pH} 7.0$ and 9.0. At $\mathrm{pH} 6.0$, only $25 \%$ of the activity remained, and this reduction in the activity became more pronounced with increasing acid $(\mathrm{pH} 3.0$ to 5.0) and basic ( $\mathrm{pH} 10$ and 11) conditions. Fig. 1(B) shows the stability at $\mathrm{pH}$ between 7.0 and 9.0 , during $24 \mathrm{~h}$ of incubation at $4{ }^{\circ} \mathrm{C}$. The enzyme was quite stable between $\mathrm{pH} 7.0$ and 9.0, retaining about $85-90 \%$ of its initial activity, even after $24 \mathrm{~h}$.

Fig. 2(A) shows the optimum temperature for the collagenase activity at $37{ }^{\circ} \mathrm{C}$. Above $45{ }^{\circ} \mathrm{C}$, the enzyme activity was gradually decreased until its complete inhibition at 55, 65 and $75^{\circ} \mathrm{C}$. Fig. 2(B) shows the effects of the temperature on the enzyme stability over $6 \mathrm{~h}$. The enzyme stability, tested at two temperatures, was maintained by approximately 90\% of its activity even after $6 \mathrm{~h}$.

The substrate specificity of enzyme was tested using azocoll, collagen (types I and V), gelatin and azocasein. The highest activity was obtained with azocoll $(700 \mathrm{U} / \mathrm{mL})$, considered as $100 \%$. The relative activities for the other substrates tested were lower, reaching about $20 \%$ by using gelatin and type I collagen, $52 \%$ using type $\mathrm{V}$ collagen and $2 \%$ in the tests with azocasein.

The evaluation of the effect of inhibitors on the extracted collagenase enzyme showed that after $30 \mathrm{~min}$ of incubation at $37^{\circ} \mathrm{C}$ and in presence of $10 \mathrm{mM}$ of PMSF (that inhibits serine proteases), the enzyme activity was reduced to 0 (indicative of serine protease), whilst in the presence of $10 \mathrm{mM}$ iodoacetic acid (that inhibits cysteine proteases) a residual activity of $80.22 \%$ was maintained. The collagenolytic enzyme was slightly inhibited by EDTA (that inhibits metalloproteinases), with a loss of only about $5 \%$ of the
A

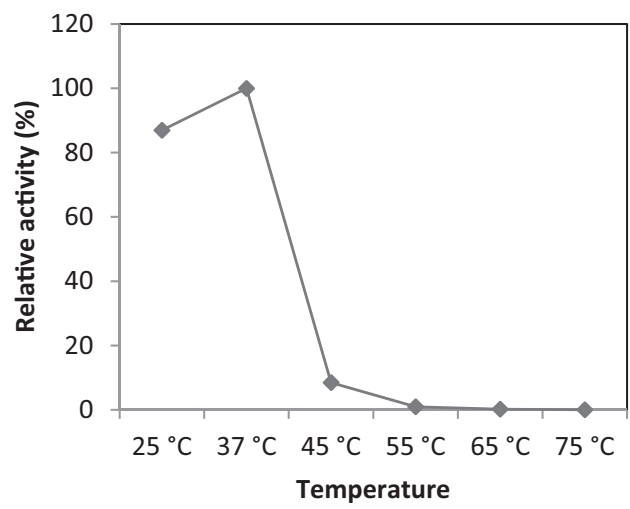

B

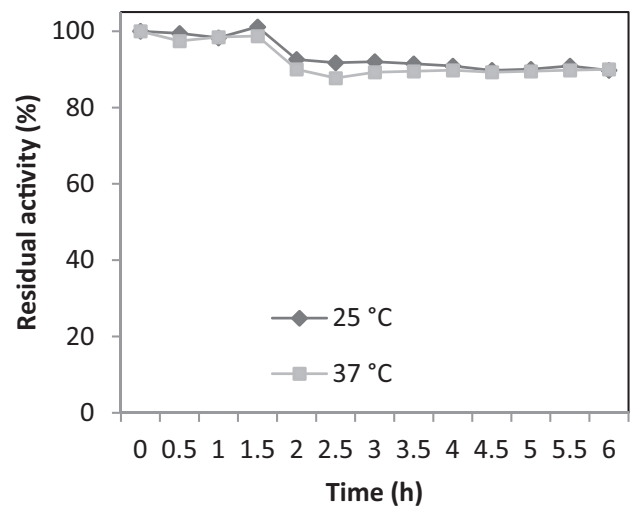

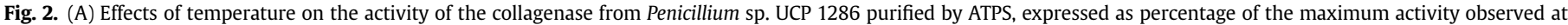

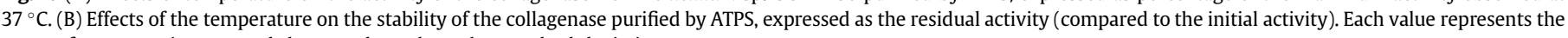
mean of two experiments, and the error bars show the standard deviations. 
A

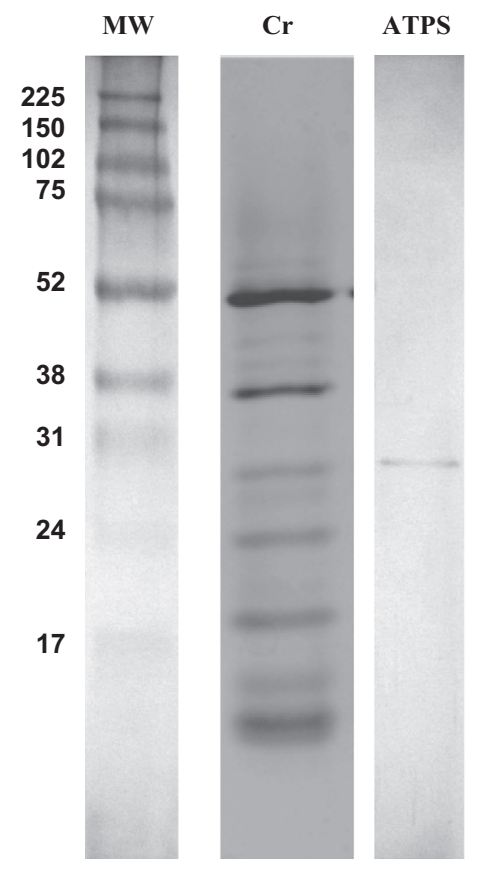

B

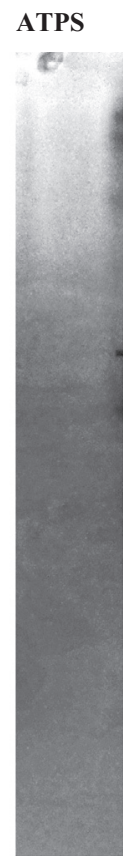

Fig. 3. (A) SDS-PAGE patterns of the collagenase from Penicillium sp. UCP 1286 purified by ATPS and crude extract (Cr), MW: molecular weight. (B) Zymogram analysis of the purified collagenase.

enzyme activity.

The electrophoresis and zymogram of the purified collagenase by ATPS are presented in Fig. $3 \mathrm{~A}$ and B, respectively. The purified enzyme presented a single band in the polyacrylamide gel electrophoresis, corresponding to a molecular weight (MW) of approximately $28 \mathrm{kDa}$, while crude extract showed multiples bands (Fig. 3A). Zymogram analysis (Fig. 3B) confirmed bands with collagenolytic activity.

\section{Conclusions}

The extraction and partition of a collagenase produced by Penicillium sp. UCP 1286 based in aqueous two-phase system (ATPS) was effective. The yield and partition coefficient were satisfactory when compared to previous reports regarding the potential of ATPS to purify collagenases. The center point runs presented the best values of yield and partition coefficient, while the PEGMM and the $\mathrm{pH}$ affected differently the enzyme purification factor (positively and negatively, respectively). The enzyme presented optimal collagenolytic activity at $37^{\circ} \mathrm{C}$ and $\mathrm{pH} 9$, was stable in relation to $\mathrm{pH}$ and temperature and suggested to be a serine protease (as shown by inhibition by PMSF). A single band in the SDS/PAGE electrophoresis confirmed ATPS as a rapid and low cost method for the collagenase purification.

\section{Ethical statement/conflict of interest}

The authors are aware of the ethical responsibilities and the manuscript has no conflict of interest.

\section{Acknowledgments}

This work was supported by the National Council of Technological and Scientific Development (CNPq) and Coordination for the

Improvement of Higher Education Personnel (CAPES). Sara Silvério also acknowledges her post-doc grant (SFRH/BPD/88584/2012) from FCT (SFRH/BPD/88584/2012) (Portuguese Science and Technology Foundation), Portugal.

\section{References}

[1] G. a. Di Lullo, S.M. Sweeney, J. Körkkö, L. Ala-Kokko, J.D. San Antonio, Mapping the ligand-binding sites and disease-associated mutations on the most abundant protein in the human, type I collagen, J. Biol. Chem. 277 (2002) 4223-4231, http://dx.doi.org/10.1074/jbc.M110709200.

[2] W.E.G. Müller, The origin of metazoan complexity: porifera as integrated animals, Integr. Comp. Biol. 43 (2003) 3-10, http://dx.doi.org/10.1093/icb/ 43.1.3.

[3] L.H. Tran, H. Nagano, Isolation and characteristics of Bacillus subtilis CN2 and its collagenase production, Food Microbiol. Saf. 67 (2002) 3-6.

[4] H.S. Hamdy, Extracellular collagenase from Rhizoctonia solani : production, purification and characterization, Indian J. Biotechnol. 7 (2008) 333-340.

[5] Q. Wu, C. Li, C. Li, H. Chen, L. Shuliang, Purification and characterization of a novel collagenase from Bacillus pumilus Col-J, Appl. Biochem. Biotechnol. 160 (2010) 129-139, http://dx.doi.org/10.1007/s12010-009-8673-1.

[6] C.A. Lima, J.L.L. Filho, B.B. Neto, A. Converti, M.G. Carneiro da Cunha, A.L.F. Porto, Production and characterization of a collagenolytic serine proteinase by Penicillium aurantiogriseum URM 4622: a factorial study, Biotechnol. Bioprocess Eng. 16 (2011) 549-560, http://dx.doi.org/10.1007/ s12257-010-0247-0.

[7] C.A. Lima, A.C.V.F. Júnior, J.L.L. Filho, A. Converti, D. a. V. Marques, M.G. Carneiro-da-Cunha, A.L.F. Porto, Two-phase partitioning and partial characterization of a collagenase from Penicillium aurantiogriseum URM4622: application to collagen hydrolysis, Biochem. Eng. J. 75 (2013) 64-71, http:// dx.doi.org/10.1016/j.bej.2013.03.012.

[8] L. Ravanti, V.M. Kahari, Matrix metalloproteases in wound repair, Int. J. Mol. Med. 6 (2000) 391-407.

[9] C.A. Lima, J.F. Campos, J.L.L. Filho, A. Converti, M.G.C. da Cunha, A.L.F. Porto, Antimicrobial and radical scavenging properties of bovine collagen hydrolysates produced by Penicillium aurantiogriseum URM 4622 collagenase, J. Food Sci. Technol. 52 (2014) 4459-4466, http://dx.doi.org/10.1007/s13197-0141463-y.

[10] Z. Li, W. Youravong, A. H-Kittikun, Separation of proteases from yellowfin tuna spleen by ultrafiltration, Bioresour. Technol. 97 (2006) 2364-2370, http://dx.doi.org/10.1016/j.biortech.2005.10.019.

[11] M.C. McMaster, HPLC: a Practical Users Guide, second ed., Wiley, New York, 2007.

[12] M. Yavari, G.R. Pazuki, M. Vossoughi, S.A. Mirkhani, A.A. Seifkordi, Partitioning of alkaline protease from Bacillus licheniformis (ATCC 21424) using PEG - K 2 HPO 4 aqueous two-phase system, Fluid Phase Equilib. 337 (2013) 1-5.

[13] B.U. Rosso, C.D.A. Lima, T.S. Porto, C. de Oliveira Nascimento, A. Pessoa, A. Converti, M.D.G. Carneiro-da-Cunha, A.L.F. Porto, Partitioning and extraction of collagenase from Penicillium aurantiogriseum in poly(ethylene glycol)/ phosphate aqueous two-phase system, Fluid Phase Equilib. 335 (2012) 20-25, http://dx.doi.org/10.1016/j.fluid.2012.05.030.

[14] J. a. Asenjo, B. a. Andrews, Aqueous two-phase systems for protein separation: a perspective, J. Chromatogr. A 1218 (2011) 8826-8835, http://dx.doi.org/ 10.1016/j.chroma.2011.06.051.

[15] P.A. Albertsson, Separation of Cell Particles and Molecules, vol. 1, Wiley, New York, 1986, p. 1993.

[16] M. Iqbal, Y. Tao, S. Xie, Y. Zhu, D. Chen, X. Wang, L. Huang, D. Peng, A. Sattar, M.A.B. Shabbir, H.I. Hussain, S. Ahmed, Z. Yuan, Aqueous two-phase system (ATPS): an overview and advances in its applications, Biol. Proced. Online 18 (2016) 18, http://dx.doi.org/10.1186/s12575-016-0048-8.

[17] A.M. Azevedo, a. G. Gomes, P. a. J. Rosa, I.F. Ferreira, A.M.M.O. Pisco, M.R. AiresBarros, Partitioning of human antibodies in polyethylene glycol-sodium citrate aqueous two-phase systems, Sep. Purif. Technol. 65 (2009) 14-21, http:// dx.doi.org/10.1016/j.seppur.2007.12.010.

[18] B. Kavakçioǧlu, L. Tarhan, Initial purification of catalase from Phanerochaete chrysosporium by partitioning in poly(ethylene glycol)/salt aqueous two phase systems, Sep. Purif. Technol. 105 (2013) 8-14, http://dx.doi.org/ 10.1016/j.seppur.2012.12.011.

[19] D.A.V. Marques, V.C. Santos-Ebinuma, A. Pessoa-Júnior, B.R. Torres, A.L.F. Porto, A. Converti, Effect of aeration and agitation on extractive fermentation of clavulanic acid by using aqueous two-phase system, Biotechnol. Prog. (2016) 1-34, http://dx.doi.org/10.1002/btpr.

[20] C.S. Silva, E. Bovarotti, M.I. Rodrigues, C.O. Hokka, M. Barboza, Evaluation of the effects of the parameters involved in the purification of clavulanic acid from fermentation broth by aqueous two-phase systems, Bioprocess Biosyst. Eng. 32 (2009) 625-632, http://dx.doi.org/10.1007/s00449-008-0285-6.

[21] M.D.H.C. Maciel, C. a. Ottoni, P.N. Herculano, T.S. Porto, A.L.F. Porto, C. Santos, N. Lima, K. a. Moreira, C. Souza-Motta, Purification of polygalacturonases produced by Aspergillus Niger using an aqueous two-phase system, Fluid Phase Equilib. 371 (2014) 125-130, http://dx.doi.org/10.1016/ j.fluid.2014.03.018.

[22] M.C.B. Pimentel, a. I. Ara??jo, Z.M.B. Figueiredo, R. a. Silva, M.T.H. Cavalcanti, K. a. Moreira, J.L.L. Filho, a. L.F. Porto, Aqueous two-phase system for citrinin 
extraction from fermentation broth, Sep. Purif. Technol. 110 (2013) 158-163, http://dx.doi.org/10.1016/j.seppur.2013.03.021.

[23] N. Imelio, A. Marini, D. Spelzini, G. Picó, B. Farruggia, Pepsin extraction from bovine stomach using aqueous two-phase systems: molecular mechanism and influence of homogenate mass and phase volume ratio, J. Chromatogr. B Anal. Technol. Biomed. Life Sci. 873 (2008) 133-138, http://dx.doi.org/ 10.1016/j.jchromb.2008.07.006.

[24] A.P.B. Rabelo, E.B. Tambourgi, A. Pessoa, Bromelain partitioning in two-phase aqueous systems containing PEO-PPO-PEO block copolymers, J. Chromatogr. B Anal. Technol. Biomed. Life Sci. 807 (2004) 61-68, http://dx.doi.org/10.1016/ j.jchromb.2004.03.029.

[25] B.R. Babu, N.K. Rastogi, K.S.M.S. Raghavarao, Liquid-liquid extraction of bromelain and polyphenol oxidase using aqueous two-phase system, Chem. Eng. Process. Process Intensif. 47 (2008) 83-89, http://dx.doi.org/10.1016/ j.cep.2007.08.006.

[26] L.V. Rodríguez-Durán, D. Spelzini, V. Boeris, C.N. Aguilar, G.A. Picó, Partition in aqueous two-phase system: its application in downstream processing of tannase from Aspergillus Niger, Colloids Surfaces B Biointerfaces 101 (2013) 392-397, http://dx.doi.org/10.1016/j.colsurfb.2012.07.023.

[27] F. Rahimpour, G. Mamo, F. Feyzi, S. Maghsoudi, R. Hatti-Kaul, Optimizing refolding and recovery of active recombinant Bacillus halodurans xylanase in polymer-salt aqueous two-phase system using surface response analysis, J. Chromatogr. A 1141 (2007) 32-40, http://dx.doi.org/10.1016/ j.chroma.2006.11.053.

[28] V. Ramakrishnan, L.C. Goveas, N. Suralikerimath, C. Jampani, P.M. Halami, B. Narayan, Extraction and purification of lipase from Enterococcus faecium MTCC5695 by PEG/phosphate aqueous-two phase system (ATPS) and its biochemical characterization, Biocatal. Agric. Biotechnol. 6 (2016) 19-27, http://dx.doi.org/10.1016/j.bcab.2016.02.005.

[29] A.W.F. Duarte, A.M. Lopes, J.V.D. Molino, A. Pessoa, L.D. Sette, Liquid-liquid extraction of lipase produced by psychrotrophic yeast Leucosporidium scottii L117 using aqueous two-phase systems, Sep. Purif. Technol. 156 (2015) 215-225, http://dx.doi.org/10.1016/j.seppur.2015.10.001.

[30] C.W. Ooi, S.L. Hii, S.M.M. Kamal, A. Ariff, T.C. Ling, Extractive fermentation using aqueous two-phase systems for integrated production and purification of extracellular lipase derived from Burkholderia pseudomallei, Process Biochem. 46 (2011) 68-73, http://dx.doi.org/10.1016/j.procbio.2010.07.014.

[31] Y. Xu, G. He, J. Li, Effective Extraction of Elastase from Bacillus Sp. Fermentation Broth Using Aqueous Two-phase System vol. 6, J. Zhejiang Univ. Sci. B, 2005, pp. 1087-1094, http://dx.doi.org/10.1631/jzus.2005.B1087.

[32] B. Bertrand, K. Mayolo-Deloisa, M. González-González, R. Tinoco-Valencia, L. Serrano-Carreón, F. Martínez-Morales, M.R. Trejo-Hernández, M. Rito-Palomares, Pleurotus ostreatus laccase recovery from residual compost using aqueous two-phase systems, J. Chem. Technol. Biotechnol. 91 (2016) 2235-2242, http://dx.doi.org/10.1002/jctb.4995.

[33] G.M. de Medeiros e Silva, D.D.A. Viana Marques, T.S. Porto, J.L.L. Filho, J.A.C. Teixeira, A. Pessoa-Júnior, A.L.F. Porto, Extraction of fibrinolytic proteases from Streptomyces sp. DPUA1576 using PEG-phosphate aqueous twophase systems, Fluid Phase Equilib. 339 (2013) 52-57, http://dx.doi.org/ 10.1016/j.fluid.2012.11.033.
[34] T.P. Nascimento, A.E. Sales, C.S. Porto, R.M.P. Brandão, G.M. de Campos-Takaki, J.A.C. Teixeira, T.S. Porto, A.L.F. Porto, A. Converti, Purification of a fibrinolytic protease from Mucor subtilissimus UCP 1262 by aqueous two-phase systems (PEG/sulfate), J. Chromatogr. B 1025 (2016) 16-24, http://dx.doi.org/10.1016/ j.jchromb.2016.04.046.

[35] C.A. Lima, D.A.V. Marques, B.B. Neto, J.L. Lima Filho, M.G. Carneiro-da-Cunha, A.L.F. Porto, Fermentation medium for collagenase production by Penicillium aurantiogriseum URM4622, Biotechnol. Prog. J. 27 (2011) 1470-1477.

[36] R.J. Chavira, T.J. Burnett, J.H. Hageman, Assaying proteinases with azocoll, Anal. Biochem. 136 (1984) 446-450.

[37] M.M. Bradford, A rapid and sensitive method for the quantitation of microgram quantities of protein utilizing the principle of protein-dye binding, Anal. Biochem. 72 (1976) 248-254.

[38] H. Rosen, A modified ninhydrin colorimetric analysis for amino acids, Arch. Biochem. Biophys. 67 (1975) 10-15.

[39] S. Moore, W.H. Stein, Photometric ninhydrin method for use in the chromatography of amino acids, J. Biol. Chem. 176 (1948) 367-388.

[40] U.K. Laemmli, Cleavage of structural proteins during the assembly of the head of bacteriophage T4, Nature 227 (1970) 680-685.

[41] T.S. Porto, G.M. Medeiros e Silva, C.S. Porto, M.T.H. Cavalcanti, B.B. Neto J.L. Lima-Filho, A. Converti, A.L.F. Porto, A. Pessoa, Liquid-liquid extraction of proteases from fermented broth by PEG/citrate aqueous two-phase system Chem. Eng. Process. Process Intensif. 47 (2008) 716-721, http://dx.doi.org/ 10.1016/j.cep.2006.12.004

[42] A. Sundaresan, M. Babu, D. Thyagarajan, R.A. Rajini, Evaluation of Meat Byproduct - Ossein in Commercial Broiler Chicken Performance, vol. 91, 2014 pp. 56-58.

[43] I.P. Trindade, M.M. Diogo, D.M.F. Prazeres, J.C. Marcos, Purification of plasmid DNA vectors by aqueous two-phase extraction and hydrophobic interaction chromatography, J. Chromatogr. A 1082 (2005) 176-184, http://dx.doi.org/ 10.1016/j.chroma.2005.05.079.

[44] S. Saravanan, J.R. Rao, B.U. Nair, T. Ramasami, Aqueous two-phase poly(ethylene glycol)-poly(acrylic acid) system for protein partitioning: influence of molecular weight, $\mathrm{pH}$ and temperature, Process Biochem. 43 (2008) 905-911, http://dx.doi.org/10.1016/j.procbio.2008.04.011.

[45] P. Vats, U.C. Banerjee, Catalytic characterization of phytase (myo-inositolhexakisphosphate phosphohydrolase) from Aspergillus Niger van Teighem: glycosylation pattern, kinetics and molecular properties, Enzyme Microb. $\begin{array}{llll}\text { Technol. } & 39 & \text { (2006) } & \text { 596-600, http://dx.doi.org/10.1016/ }\end{array}$ j.enzmictec.2005.11.009.

[46] M. Rito-Palomares, Practical application of aqueous two-phase partition to process development for the recovery of biological products, J. Chromatogr. B Anal. Technol. Biomed. Life Sci. 807 (2004) 3-11, http://dx.doi.org/10.1016/ j.jchromb.2004.01.008.

[47] A. Endo, S. Murakawa, H. Shimizu, Y. Shiraishi, Purification and properties of collagenase from a Streptomyces species, J. Biochem. 102 (1987) 163-170.

[48] T.J. Leighton, R.H. Doi, R.A.J. Warren, et al., The relationship of serine protease activity to RNA poly-merase modification and sporulation in Bacillus subtilis, J. Mol. Biol. 76 (1973) 103-122. 